\title{
Thinking versus feeling: Differentiating between cognitive and affective components of perceived cancer risk
}

Citation for published version (APA):

Janssen, E., van Osch, L., Lechner, L., Candel, M., \& de Vries, H. (2012). Thinking versus feeling: Differentiating between cognitive and affective components of perceived cancer risk. Psychology \& Health, 27(7), 767-783. https://doi.org/10.1080/08870446.2011.580846

Document status and date:

Published: 01/01/2012

DOI:

10.1080/08870446.2011.580846

Document Version:

Publisher's PDF, also known as Version of record

\section{Document license:}

Taverne

\section{Please check the document version of this publication:}

- A submitted manuscript is the version of the article upon submission and before peer-review. There can be important differences between the submitted version and the official published version of record. People interested in the research are advised to contact the author for the final version of the publication, or visit the DOI to the publisher's website.

- The final author version and the galley proof are versions of the publication after peer review.

- The final published version features the final layout of the paper including the volume, issue and page numbers.

Link to publication

\footnotetext{
General rights rights.

- You may freely distribute the URL identifying the publication in the public portal. please follow below link for the End User Agreement:

www.umlib.nl/taverne-license

Take down policy

If you believe that this document breaches copyright please contact us at:

repository@maastrichtuniversity.nl

providing details and we will investigate your claim.
}

Copyright and moral rights for the publications made accessible in the public portal are retained by the authors and/or other copyright owners and it is a condition of accessing publications that users recognise and abide by the legal requirements associated with these

- Users may download and print one copy of any publication from the public portal for the purpose of private study or research.

- You may not further distribute the material or use it for any profit-making activity or commercial gain

If the publication is distributed under the terms of Article $25 \mathrm{fa}$ of the Dutch Copyright Act, indicated by the "Taverne" license above, 


\section{Thinking versus feeling: Differentiating between cognitive and affective components of perceived cancer risk}

Eva Janssen, Liesbeth van Osch , Lilian Lechner , Math Candel \& Hein de Vries

To cite this article: Eva Janssen, Liesbeth van Osch, Lilian Lechner, Math Candel \& Hein de Vries (2012) Thinking versus feeling: Differentiating between cognitive and affective components of perceived cancer risk, Psychology \& Health, 27:7, 767-783, DOI: 10.1080/08870446.2011.580846

To link to this article: https://doi.org/10.1080/08870446.2011.580846

曲 Published online: 18 Jul 2011.

Submit your article to this journal

Џ Article views: 803

Q View related articles $\asymp$

4 Citing articles: 10 View citing articles 


\title{
Thinking versus feeling: Differentiating between cognitive and affective components of perceived cancer risk
}

\author{
Eva Janssen ${ }^{\mathrm{a} *}$, Liesbeth van Osch ${ }^{\mathrm{a}}$, Lilian Lechner ${ }^{\mathrm{b}}$, \\ Math Candel ${ }^{\mathrm{c}}$ and Hein de Vries ${ }^{\mathrm{a}}$
}

\begin{abstract}
${ }^{a}$ School for Public Health and Primary Care (Caphri), Department of Health Promotion, Faculty of Health, Medicine and Life Sciences, Maastricht University, Maastricht, The Netherlands; ${ }^{b}$ School for Public Health and Primary Care (Caphri), Faculty of Psychology, Open University of the Netherlands, Heerlen, The Netherlands; ${ }^{c}$ School for Public Health and Primary Care (Caphri), Department of Methodology and Statistics, Faculty of Health, Medicine and Life Sciences, Maastricht University, Maastricht, The Netherlands
\end{abstract}

(Received 5 January 2011; final version received 8 April 2011)

\begin{abstract}
Despite the increased recognition of affect in guiding probability estimates, perceived risk has been mainly operationalised in a cognitive way and the differentiation between rational and intuitive judgements is largely unexplored. This study investigated the validity of a measurement instrument differentiating cognitive and affective probability beliefs and examined whether behavioural decision making is mainly guided by cognition or affect. Data were obtained from four surveys focusing on smoking $(N=268)$, fruit consumption $(N=989)$, sunbed use $(N=251)$ and sun protection $(N=858)$. Correlational analyses showed that affective likelihood was more strongly correlated with worry compared to cognitive likelihood and confirmatory factor analysis provided support for a two-factor model of perceived likelihood instead of a one-factor model (i.e. cognition and affect combined). Furthermore, affective likelihood was significantly associated with the various outcome variables, whereas the association for cognitive likelihood was absent in three studies. The findings provide support for the construct validity of the measures used to assess cognitive and affective likelihood. Since affective likelihood might be a better predictor of health behaviour than the commonly used cognitive operationalisation, both dimensions should be considered in future research.
\end{abstract}

Keywords: risk perception; cancer; risk assessment; cognition and affect; feeling at risk

\section{Introduction}

Perceptions of risk likelihood play a central role in theories of health-protective behaviours (e.g. de Vries et al., 2003; Janz \& Becker, 1984; Rogers, 1975; Schwarzer, 1999) and in research explaining cancer-related behaviours (e.g. sunscreen use and

*Corresponding author. Email: Eva.janssen@maastrichtuniversity.nl 
smoking cessation; de Vries, Lezwijn, Hol, \& Honing, 2005; Norman, Conner, \& Bell, 1999). The estimates people make about their risk of developing cancer have important implications for cancer prevention since they guide cancer protective behaviours (Peters, McCaul, Stefanek, \& Nelson, 2006).

For a long time, perceived likelihood has been treated as a unitary construct, mainly operationalised as 'cold cognitions', independent from affect (Berndsen \& van der Pligt, 2005; Waters, 2008; Windschitl, 2003). However, in daily life, people often distinguish what they feel from what they think when dealing with likelihood estimates. People are often aware that their chances are small or big but this may diverge from what their feeling tells them. For example, people frequently experience uncomfortable feelings about hazards they know at a rational level are highly unlikely (e.g. airplane crashes), while they experience little negative feelings about hazards that are more likely to occur (e.g. car accidents) (Loewenstein, Weber, Hsee, \& Welch, 2001; Windschitl, 2003). Similarly, in a study of Denes-Raj and Epstein (1994), people who were offered to win \$1 by drawing a red jelly bean were more likely to draw from a bowl that contained a greater absolute number, but a smaller proportion of red beans (e.g. 7 in 100) than from a bowl with fewer red beans but a better probability of winning (e.g. 1 in 10). Participants reported that although they knew the probabilities were against them, they felt they had a better chance when there were more red beans. The important role of affect in guiding probability estimates has been acknowledged increasingly in the past decade (Klein \& Stefanek, 2007; Loewenstein et al., 2001; Peters et al., 2006; Slovic, Peters, Finucane, \& MacGregor, 2005; Weinstein et al., 2007; Windschitl, 2003), indicating that perceived likelihood is not only based on what people think, but also on what people feel. Hence, when people think about their risk, affective factors may influence their risk estimates and their response to health risk messages. The reliance on feelings in making judgements and decisions is in line with the affect heuristic, assuming that affect may serve as a cue for many important judgements (Slovic et al., 2005).

These different types of judgements (rational vs. intuitive or affective) may be related to the broader distinction between two ways in which risks are being processed. This 'dual-process' reasoning distinguishes between an analytic system, in which risks are processed in a deliberative way using normative rules, and the more emotionally loaded experiential system, in which risks are processed faster and in a more intuitive way based on associations (Epstein, Lipson, Holstein, \& Huh, 1992; Loewenstein et al., 2001; Slovic et al., 2005). Both systems interact and are continually active, but depending on the situation and nature of the judgement or decision, people may rely more heavily on one of the two systems. Because people have limited resources (e.g. in terms of time and cognitive and computational abilities) to deal with the numerous decisions and information they face daily, it is conceivable that intuitive feelings may be an important method by which people evaluate risks since, in accordance with Slovic et al. (2005), 'reliance on affect is a quicker, easier, and more efficient way to navigate in a complex and uncertain world' (p. S35).

However, in most research on risk perception up till now, risk perception is still operationalised in a cognitive way (e.g. Bränström, Kristjansson, Ullén, \& Brandberg, 2002; Cohen, 2006; Vernon, 1999). It has therefore been suggested to include the consideration of affective processing of risk when measuring perceived likelihood (e.g. Janssen, van Osch, de Vries, \& Lechner, 2010; Loewenstein et al., 2001; Windschitl, 2003), for example by distinguishing between more cognitive ('rational') and affective ('intuitive') probability beliefs, since either or both 
components can drive protective behaviour (Janssen et al., 2010; Windschitl, 2003). Windschitl (2003) proposed the design of measures that separately evaluate objective beliefs (referred to as cognitive likelihood in this study) and intuitive feelings (referred to as affective likelihood in this study) using, for example, instructions that optimise the use of objective reasoning (e.g. 'What is the objective likelihood that you will get disease X?') or intuitive gut-level responses (e.g. 'How do you feel your chances are of getting disease X?'). Two recent studies that explicitly distinguished between cognitive and affective risk perception found differences in the relationship between self-protective behaviours and cognitive and affective likelihood (Janssen et al., 2010; Weinstein et al., 2007). In both studies, affective likelihood was more strongly correlated with health behaviour compared to cognitive likelihood. Although these results provide a first indication that a cognitive and affective component of risk perception can be discerned by asking about objective probability beliefs and feeling at risk, they do not exclude the possibility that both measurements are actually measuring the same underlying construct (i.e. questions about believing versus feeling at risk may not be conceptually different), and differ, for example, only in the way people respond to these questions. Hence, the validity of such a juxtaposition of cognitive and affective likelihood measures has not yet been examined.

The first objective of this study is therefore to verify the ability of cognitive and affective likelihood scales to measure the cognitive and affective components of perceived likelihood by testing two hypotheses. The first hypothesis is that affective likelihood correlates stronger with other affective constructs (i.e. worry). Worry has been defined by Borkovec, Robinson, Pruzinsky, and DePree (1983) as a chain of thoughts and images, which are negatively affect-laden and relatively uncontrollable. A growing body of evidence indicates that worry predicts health promoting behaviours (e.g. Cameron \& Reeve, 2006; Hay, McCaul, \& Magnan, 2006; McCaul $\&$ Mullens, 2003). Since worry can be considered as an affectively laden construct tending to refer to emotional reactions, it is hypothesised that this construct is more strongly correlated with affective risk perception compared to cognitive risk perception, referring to a more rational judgement. Second, the hypothesis was tested that factor analysis would reveal a cognitive and an affective factor juxtaposing beliefs about objective probability and intuitive risk judgements. The second objective of this study was to assess the associations of cognitive and affective likelihood with four different cancer related behaviours or behavioural intentions in order to examine whether the decision making process is mainly guided by cognition or affect. Since affective perceptions of perceived likelihood were more strongly related to health behaviours in other domains (e.g. Weinstein et al., 2007), we hypothesised that affective likelihood is a stronger correlate of cancer-related behaviours. These insights will have important implications for cancer risk communication practices since they will indicate whether more importance should be given to either people's thoughts or feelings.

\section{Methods}

\section{Respondents and procedures}

Data were obtained from four online surveys conducted in the Netherlands, focusing on several cancer-related risk behaviours: smoking (Study 1), fruit consumption 


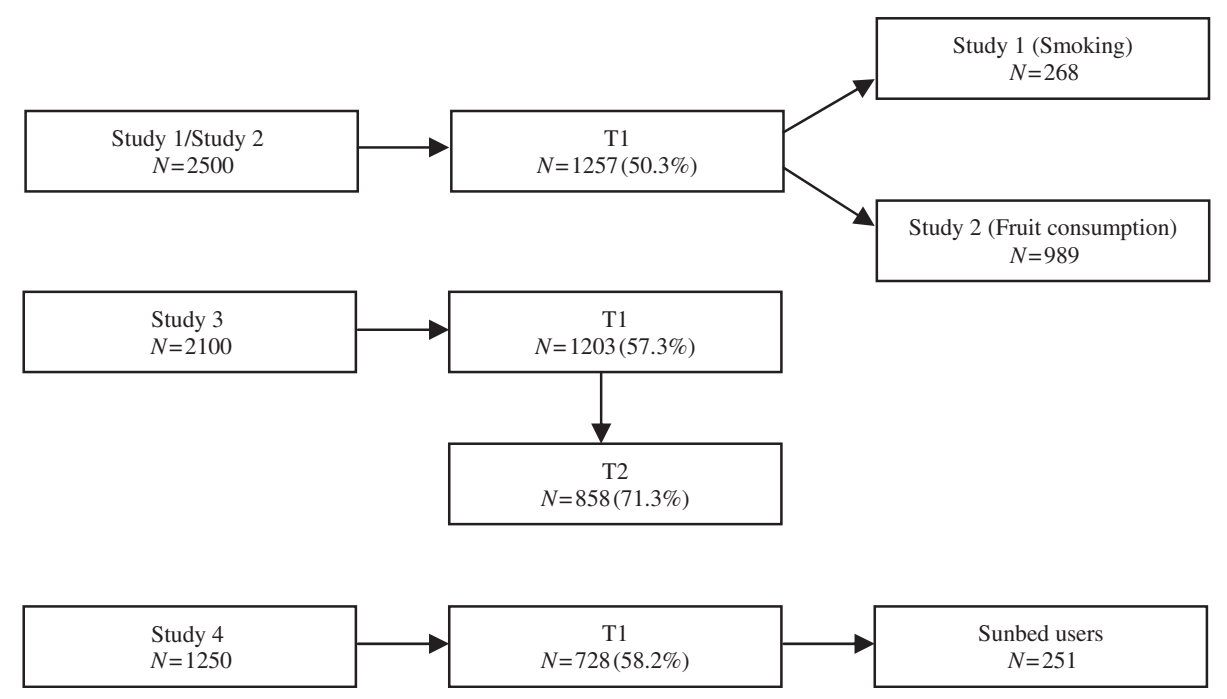

Figure 1. Sample sizes of the four studies.

(Study 2), sun protection (Study 3), and sunbed use (Study 4). In Studies 1 and 4, intention was used as the outcome measure (i.e. intention to quit smoking and intention to quit using sunbeds). The study samples consisted of Dutch adults ( $>40$ years in Studies 1 and 2; >18 years in Studies 3 and 4) that were all registered members of an online survey panel of one of two private research companies. A total of 2500 participants were invited by e-mail to participate in Study 1 or Study 2. Participants who reported positive smoking status, were assigned to Study 1, whereas participants who reported a negative smoking status, were assigned to Study 2. For Study 3, a total of 2100 participants were invited to participate. A total of 1250 participants were invited to participate in Study 4, and only participants who reported to use sunbeds were included. Participants were asked to fill in one questionnaire, except for Study 3 on sun protection where participants were asked to fill in a questionnaire before and after ( 5 months later) the summer. In all studies, participants were explained that confidentiality would be ensured, and that they would receive a small incentive after completing the questionnaire(s). By activating a link in the invitation e-mail, participants were directed to the online questionnaire. Information about the sample sizes of the four studies are presented in Figure 1 and characteristics of the study samples are depicted in Table 1.

\section{Measures}

In the baseline questionnaires of the four studies, perceived cognitive likelihood, perceived affective likelihood, worry, and relevant demographic variables were measured. Furthermore, the outcome variables were measured at baseline in Studies 1, 2 and 4 (i.e. intention to quit smoking, current fruit consumption and intention to quit using sunbeds, respectively). At follow-up in Study 3, sun protective behaviour was measured. 
Table 1. Characteristics of the study samples.

\begin{tabular}{|c|c|c|c|c|}
\hline & $\begin{array}{l}\text { Study 1: } \\
\text { smoking } \\
(N=268)\end{array}$ & $\begin{array}{c}\text { Study 2: } \\
\quad \text { fruit } \\
\text { consumption } \\
(N=989)\end{array}$ & $\begin{array}{l}\text { Study } 3: \\
\text { sun } \\
\text { protection } \\
(N=1203)\end{array}$ & $\begin{array}{c}\text { Study 4: } \\
\text { sunbed } \\
\text { use } \\
(N=251)\end{array}$ \\
\hline \multicolumn{5}{|l|}{ Gender } \\
\hline Women $(\%)$ & 46.3 & 51.6 & 47.3 & 70.1 \\
\hline Mean age (SD) & $51.2(7.68)$ & $51.0(8.04)$ & $36.6(8.55)$ & $43.5(10.13)$ \\
\hline \multicolumn{5}{|l|}{ Educational level } \\
\hline Low $(\%)$ & 24.6 & 17.7 & 10.9 & 5.2 \\
\hline Medium (\%) & 63.1 & 62.0 & 57.3 & 53.3 \\
\hline High $(\%)$ & 12.3 & 20.4 & 31.8 & 41.5 \\
\hline $\begin{array}{l}\text { Mean intention to quit } \\
\text { smoking (SD) }\end{array}$ & $3.08(1.10)$ & & & \\
\hline $\begin{array}{l}\text { Mean current fruit } \\
\text { consumption (SD) }\end{array}$ & & $1.23(0.98)$ & & \\
\hline Mean sun protection (SD) & & & $3.24(1.04)$ & \\
\hline $\begin{array}{l}\text { Mean intention to } \\
\text { quit sunbed use (SD) }\end{array}$ & & & & $2.58(0.98)$ \\
\hline
\end{tabular}

\section{Perceived likelihood}

The perceived cognitive and affective likelihood measures were based on previous research (Janssen et al., 2010; Weinstein et al., 2007). All perceived likelihood items were measured in a conditional way (i.e. the risk questions were conditioned on not performing the adaptive behaviour) in order to prevent that people infer their probability estimate from their current behaviour (or intentions), which may lead to an underestimation of the relationship between perceived likelihood and health behaviour (Brewer et al., 2007; Janssen et al., 2010).

\section{Cognitive likelihood}

This was measured with two items in the first three studies and with four items in Study 4. For each cognitive likelihood scale, a mean score of relevant items was calculated and used for analyses. Participants were introduced to the cognitive likelihood questions in Studies 1, 2 and 4 to ensure that the difference between the cognitive and affective questions was clear. The introduction message emphasised that the subsequent questions were related to the facts about their probability to get (skin/lung) cancer.

\section{Affective likelihood}

This was measured with two items in the first three studies and with six items in Study 4. For each affective likelihood scale, a mean score of relevant items was calculated and used for analyses. Participants were introduced to the affective likelihood questions in all studies. The introduction message emphasised that the subsequent questions were related to their intuitive feelings about their probability to get (skin/lung) cancer instead of their objective probability beliefs (see Box 1 for a 
Box 1. Introduction message cognitive and affective likelihood.

The following questions involve the facts about your risk of developing skin cancer during your lifetime. These questions do not involve your feelings or intuition, but require a logical and rational response. Try to be as accurate and objective as possible when estimating your risk for skin cancer (in the same way that a medical expert or researcher would assess the situation).

The following questions involve your feelings about developing skin cancer during your lifetime. These questions do not involve logic or rationality, but require an intuitive and emotional response. When answering these questions try to follow your intuition as much as possible.

full description of the introduction message of the cognitive and affective likelihood questions and see Table 2 for a full description of the items).

\section{Worry}

In all studies, worry frequency was measured with one question asking participants how often they worry about getting (skin/lung) cancer $(1=$ never; $5=$ very often) (McCaul \& Goetz, 2008). In Studies 1, 2 and 4 also worry intensity was measured with two questions (Cameron, 2008), asking respondents how bothered they are by thinking about getting (skin/lung) cancer ( $1=$ not at all; $5=$ extremely) and how worried they are about getting (skin/lung) cancer $(1=$ not at all; $5=$ extremely). A mean score of worry frequency and intensity was calculated and used for the analyses ( $\alpha=0.81,0.80,0.77$ for Studies 1,2 and 4 , respectively).

\section{Demographics}

Gender, age and educational level were measured in the baseline questionnaire of all four studies.

\section{Outcome measures}

Intention to quit smoking. In Study 1 , this was measured with two items $(\alpha=0.90)$ (Dijkstra, De Vries, Roijackers, \& van Breukelen, 1998). The first item asked to what extent respondents intended to quit smoking. In the second question, respondents were asked to what extent they are motivated to quit smoking. For both questions, answering options ranged from $1=$ definitely not to $5=$ definitely.

Fruit consumption. The measurement of fruit consumption in Study 2 was based on a validated questionnaire (van den Brink, Ocké, Houben, van Nierop, \& Droomers, 2005 ) and consisted of two items, asking about (1) the number of days per week the respondent usually eats fruit (0-7), and (2) the amount of fruit the respondent consumes on average on each of these days. Responses to these two questions were multiplied indicating the amount of fruit consumed per week.

Sun protection. This was assessed in Study 3 by two questions based on prior research (Janssen et al., 2010). The questions asked participants whether they 
Table 2. Description of the cognitive and affective likelihood scales, Cronbach's $\alpha$ and mean (SD).

\begin{tabular}{|c|c|c|c|}
\hline Perceived likelihood & $\begin{array}{c}\text { Internal } \\
\text { consistency } \alpha\end{array}$ & Mean (SD) & $\begin{array}{l}\text { Items, answering options } \\
\text { and range }\end{array}$ \\
\hline \multicolumn{4}{|l|}{ Study 1: Smoking } \\
\hline Cognitive likelihood & 0.77 & $3.43(0.68)$ & $\begin{array}{l}\text { 1. If I keep smoking, my chances } \\
\text { of getting lung cancer at some } \\
\text { point in my life are: very small } \\
\text { (1) to very big (5) } \\
\text { 2. If I keep smoking, my chances } \\
\text { of getting lung cancer at some } \\
\text { point in my life are big: com- } \\
\text { pletely disagree (1) to comple- } \\
\text { tely agree (5) }\end{array}$ \\
\hline Affective likelihood & 0.86 & $3.18(0.78)$ & $\begin{array}{l}\text { 1. If I keep smoking, I feel: very } \\
\text { vulnerable to getting lung cancer } \\
\text { at some point in my life (1) to } \\
\text { definitely not vulnerable to get- } \\
\text { ting lung cancer at some point in } \\
\text { my life (5) } \\
\text { 2. If I keep smoking, I feel vul- } \\
\text { nerable to getting lung cancer } \\
\text { at some point in my life: com- } \\
\text { pletely disagree (1) to comple- } \\
\text { tely agree (5) }\end{array}$ \\
\hline \multicolumn{4}{|c|}{ Study 2: Fruit consumption } \\
\hline Cognitive likelihood & 0.75 & $2.81(0.58)$ & $\begin{array}{l}\text { 1. If I do not eat enough fruit, my } \\
\text { chances of getting cancer at } \\
\text { some point in my life are: very } \\
\text { small (1) to very big (5) } \\
\text { 2. If I do not eat enough fruit, my } \\
\text { chances of getting cancer at } \\
\text { some point in my life are big: } \\
\text { completely disagree (1) to com- } \\
\text { pletely agree (5) }\end{array}$ \\
\hline Affective likelihood & 0.73 & $2.54(0.69)$ & $\begin{array}{l}\text { 1. If I do not eat enough fruit, I } \\
\text { feel: very vulnerable to getting } \\
\text { cancer at some point in my life } \\
\text { (1) to definitely not vulnerable to } \\
\text { getting cancer at some point in } \\
\text { my life (5) } \\
\text { 2. If I do not eat enough fruit, I } \\
\text { feel vulnerable to getting cancer } \\
\text { at some point in my life: com- } \\
\text { pletely disagree (1) to comple- } \\
\text { tely agree (5) }\end{array}$ \\
\hline \multicolumn{4}{|l|}{ Study 3: Sun protection } \\
\hline Cognitive likelihood & 0.53 & $3.62(0.73)$ & $\begin{array}{l}\text { 1. If I do not protect my skin } \\
\text { adequately from the sun using } \\
\text { sunscreen, my chances of get- } \\
\text { ting skin cancer at some point } \\
\text { in my life are: very small (1) to } \\
\text { very big (5) }\end{array}$ \\
\hline
\end{tabular}


Table 2. Continued.

\begin{tabular}{|c|c|c|c|}
\hline Perceived likelihood & $\begin{array}{c}\text { Internal } \\
\text { consistency } \alpha\end{array}$ & Mean (SD) & $\begin{array}{c}\text { Items, answering options } \\
\text { and range }\end{array}$ \\
\hline Affective likelihood & 0.89 & $3.05(0.92)$ & $\begin{array}{l}\text { 2. If I do not protect my skin } \\
\text { adequately from the sun using } \\
\text { sunscreen, my chances of get- } \\
\text { ting skin cancer at some point } \\
\text { in my life are: much bigger than } \\
\text { when I adequately protect myself } \\
\text { (1) to definitely no bigger } \\
\text { than when I protect my skin } \\
\text { adequately (5) } \\
\text { 1. If I do not protect my skin } \\
\text { adequately from the sun using } \\
\text { sunscreen, I feel: definitely not } \\
\text { vulnerable to getting skin cancer } \\
\text { at some point in my life (1) to } \\
\text { very vulnerable to getting skin } \\
\text { cancer at some point in my } \\
\text { life (5) } \\
\text { 2. If I do not protect my skin } \\
\text { adequately from the sun using } \\
\text { sunscreen, I feel: much more } \\
\text { vulnerable to getting skin cancer } \\
\text { at some point in my life than } \\
\text { when I adequately protect myself } \\
\text { (1) to not more vulnerable to } \\
\text { getting skin cancer at some point } \\
\text { in my life than when I ade- } \\
\text { quately protect myself (5) }\end{array}$ \\
\hline
\end{tabular}

Cognitive likelihood

$0.84 \quad 3.01(0.68)$

1. If I use a sunbed, my chances of getting skin cancer at some point in my life are: very small (1) to very big (5)

2. If I use a sunbed, my chances of getting skin cancer at some point in my life are: much bigger than if I do not use a tanning bed (1) to no bigger than if I do not use a tanning bed (5)

3 . How would you estimate the likelihood of developing skin cancer at some point in your life if you use a sunbed bed?: very likely (1) to very unlikely (5)

4. If I use a sunbed, my chances of getting skin cancer at some point in my life are big: completely disagree (1) to completely agree (5)

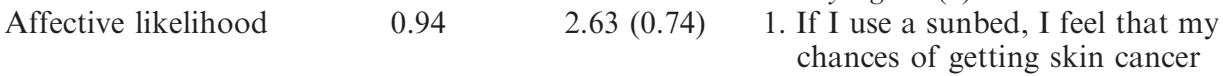


Table 2. Continued.

\begin{tabular}{|c|c|c|c|}
\hline Perceived likelihood & $\begin{array}{c}\text { Internal } \\
\text { consistency } \alpha\end{array}$ & Mean (SD) & $\begin{array}{c}\text { Items, answering options } \\
\text { and range }\end{array}$ \\
\hline & & & $\begin{array}{l}\text { at some point in my life are: } \\
\text { very small (1) to very big (5) } \\
\text { 2. If I use a sunbed, I feel: } \\
\text { definitely not vulnerable to get- } \\
\text { ting skin cancer at some point in } \\
\text { my life (1) to very vulnerable to } \\
\text { getting skin cancer at some point } \\
\text { in my life (5) } \\
\text { 3. If I use a sunbed, I feel that my } \\
\text { chances of getting skin cancer } \\
\text { at some point in my life are: } \\
\text { much bigger than when I do not } \\
\text { use a tanning bed (1) to no } \\
\text { bigger than if I do not use a } \\
\text { tanning bed (5) } \\
\text { 4. I feel that my chances of getting } \\
\text { skin cancer at some point in my } \\
\text { life are big when I use a sunbed: } \\
\text { completely agree (1) to comple- } \\
\text { tely disagree (5) } \\
\text { 5. If I use a sunbed, I feel: much } \\
\text { more vulnerable to getting skin } \\
\text { cancer at some point in my life } \\
\text { (1) to not more vulnerable to } \\
\text { getting skin cancer at some point } \\
\text { in my life (5) } \\
\text { 6. If I use a sunbed, I feel vulner- } \\
\text { able to getting skin cancer at } \\
\text { some point in my life: comple- } \\
\text { tely disagree (1) to completely } \\
\text { agree (5) }\end{array}$ \\
\hline
\end{tabular}

protected themselves adequately from the sun during the summer on traditional tanning occasions (i.e. at the beach or swimming pool) and in other outdoor situations $(1=$ never; $5=$ always $)$. On a separate preceding screen, participants were explained the definition of adequate sun protection, according to the Dutch guidelines (Dutch Cancer Society, 2007). A mean score of the two questions was calculated and used for analyses.

Intention to stop using sunbeds. In Study 4, this was measured with one question asking participants to what extent they intended to stop using sunbeds $(1=$ definitely not; 5 = definitely).

\section{Statistical analysis}

Descriptive statistics were used to describe demographic characteristics within the study sample. Pearson's $r$ was calculated between worry and cognitive and 
affective likelihood. The correlations were compared using the Fisher $z$ transformation (Meng, Rosenthal, \& Rubin, 1992). In order to test the hypothesised factorial structure, confirmatory factor analysis using maximum likelihood estimation was performed in testing a one-factor model (i.e. cognitive and affective likelihood measures combined) versus a two-factor model. Overall model fit of the two models was assessed by examining the comparative fit index (CFI), the Tucker-Lewis index (TLI), the root mean square error of approximation (RMSEA) and the standardised, root mean square residual (SRMR). High CFI and TLI $(>0.90)$ and low RMSEA and SRMR $(<0.08)$ indicate a satisfactory model fit (Hair, Anderson, Tatham, \& Black, 1998; Hu \& Bentler, 1999). Log-likelihood difference chi-squared test $\left(\chi^{2}\right)$ was used to test the difference in log-likelihood between the models. The $\chi^{2}$ index was not considered as a basic criterion for the evaluation of the model fit, since this index is dependent on the sample-size and is very sensitive to violations of the assumptions of multivariate normality (Sharma, 1996). In order to examine whether cognitive or affective likelihood is more strongly associated with behavioural intentions and behaviour, both likelihood scales were entered simultaneously in a linear regression analysis controlling for gender, age and educational level. Analyses were conducted using SPSS version 15.0 and Mplus 6.0. Statistical significance was defined as $p<0.05$.

\section{Results}

\section{Correlations between worry and cognitive versus affective likelihood (hypothesis 1)}

Pearson's correlations between worry and the cognitive and affective likelihood scales are depicted in Table 3 for all studies. In all studies, affective likelihood was more strongly correlated with worry than cognitive likelihood ( $r=0.47$ vs. 0.26 , Study $1 ; r=0.31$ vs. 0.27 , Study $2 ; r=0.48$ vs. 0.37, Study 3; $r=0.50$ vs. 0.36 , Study 4). This difference was significant in all studies $(z=-3.97$, $p<0.001$, for Study 1; $z=-2.78, p<0.01$, for Study 2; $z=-4.31, p<0.001$ for Study $3 ; z=-3.18, p<0.001$ for Study 4).

\section{Factor structure of the perceived likelihood scale (hypothesis 2)}

Factor analysis was performed to test whether two different factors (i.e. cognitive and affective) can be detected in the construct of perceived cancer risk. Table 4 presents

Table 3. Differences in correlations between worry and cognitive and affective likelihood.

\begin{tabular}{|c|c|c|c|c|}
\hline & $\begin{array}{l}\text { Study 1: } \\
\text { smoking } \\
(N=268)\end{array}$ & $\begin{array}{c}\text { Study 2: } \\
\text { fruit } \\
\text { consumption } \\
(N=989)\end{array}$ & $\begin{array}{l}\text { Study } 3: \\
\text { sun } \\
\text { protection } \\
(N=1203)\end{array}$ & $\begin{array}{l}\text { Study 4: } \\
\text { sunbed use } \\
(N=251)\end{array}$ \\
\hline Cognitive likelihood & $0.26 * *$ & $0.27 * *$ & $0.37 * *$ & $0.36 * *$ \\
\hline Affective likelihood & $0.47 * *$ & $0.31 * *$ & $0.48 * *$ & $0.50 * *$ \\
\hline$Z^{\mathrm{a}}$ & $-3.97 * * *$ & $-2.78 * *$ & $-4.31 * * *$ & $-3.18 * * *$ \\
\hline
\end{tabular}

Notes: ${ }^{\text {a}}$ Testing equality of correlations using Fisher's $r$ to $z$ transformation.

$* * p<0.01 ; * * * p<0.001$. 


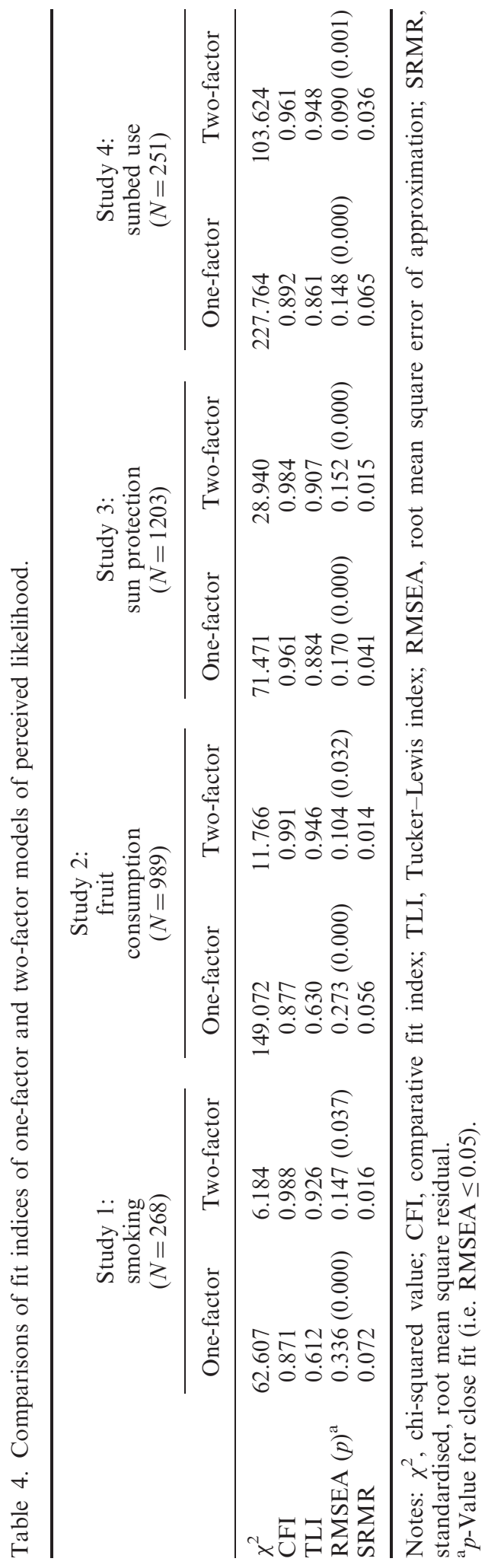


Table 5. Regression analyses.

\begin{tabular}{lcccccccc}
\hline & $\begin{array}{c}\text { Study 1: } \\
\text { smoking } \\
(N=268)\end{array}$ & $\begin{array}{c}\text { Study 2: } \\
\text { fruit consumption } \\
(N=989)\end{array}$ & $\begin{array}{c}\text { Study 3: } \\
\text { sun protection } \\
(N=858)\end{array}$ & $\begin{array}{c}\text { Study 4: } \\
\text { sunbed use } \\
(N=251)\end{array}$ \\
\hline Variable & $\beta$ & $p$ & $\beta$ & $p$ & $\beta$ & $p$ & $\beta$ & $p$ \\
Cognitive likelihood & -0.04 & 0.612 & 0.01 & 0.790 & 0.08 & 0.022 & 0.09 & 0.276 \\
Affective likelihood & 0.43 & 0.000 & 0.08 & 0.030 & 0.30 & 0.000 & 0.32 & 0.000 \\
$R^{2}$ & 0.19 & & 0.03 & & 0.16 & & 0.16 & \\
\hline
\end{tabular}

the fit indices of the two models that were tested. The analyses showed that the onefactor model did not result in a good fit of the data, whereas the fit indices of the two-factor model were satisfactory in all studies (one-factor model: CFI $=0.87-0.96$, TLI $=0.61-0.88, \quad$ RMSEA $=0.15-0.34, \quad$ SRMR $=0.04-0.07$; two-factor model: CFI $=0.96-0.99, \quad$ TLI $=0.91-0.95, \quad$ RMSEA $=0.09-0.15, \quad$ SRMR $=0.01-0.04)$. Furthermore, the log-likelihood difference $\chi^{2}$ demonstrated that the two-factor model yielded a significantly better fit of the data $\left(\Delta-2 L_{(\mathrm{MOD} 1-\mathrm{MOD} 2)}=55.79\right.$, $\mathrm{df}=1, p<0.001$ for Study $1 ; \Delta-2 \mathrm{LL}_{(\mathrm{MOD} 1-\mathrm{MOD} 2)}=137.31, \mathrm{df}=1, p<0.001$ for Study $2 ; \Delta-2 \mathrm{LL}_{(\mathrm{MOD} 1-\mathrm{MOD} 2)}=124.14, \mathrm{df}=1, p<0.001$ for Study $3 ; \Delta-2$ $\mathrm{LL}_{(\mathrm{MOD} 1-\mathrm{MOD} 2)}=42.53, \mathrm{df}=1, p<0.001$ for Study 4). All factor loadings of the two-factor models were significant with values between 0.79 and 0.91 for Study 1; 0.67 and 0.86 for Study 2; 0.68 and 0.92 for Study 3; 0.60 and 0.92 for Study 4. Correlations between the cognitive and affective factor were $0.76,0.69,0.70$, and 0.78 for Studies 1, 2, 3 and 4, respectively.

\section{Regression analyses (hypothesis 3)}

The results of the linear regression analyses, controlled for gender, age and educational level, are presented in Table 5. Affective likelihood was significantly associated with all four outcome variables $(\beta=0.43, p<0.001$ for intention to quit smoking; $\beta=0.08, p<0.05$ for fruit consumption; $\beta=0.30, p<0.001$ for sun protection; $\beta=0.32, p<0.001$ for intention to quit using sunbeds), whereas cognitive likelihood was only significantly associated with sun protection $(\beta=0.08$, $p<0.05$ ). The standardised beta coefficients suggest that affective likelihood was the strongest determinant of sun protection. The total explained variance was $19 \%, 3 \%$, $16 \%$ and $16 \%$, for intention to stop smoking, current fruit consumption, sun protection and intention to stop using sunbeds, respectively.

\section{Discussion}

The differentiation between cognitive and affective likelihood judgements has been largely unexplored. This study was an initial attempt to disentangle the perceived likelihood construct by separating cognitive and affective probability beliefs. The first objective was to investigate whether measurement instruments asking about objective likelihood beliefs versus feeling at risk are useful to tap the cognitive and affective component of perceived likelihood. The second objective was to examine whether the behavioural decision making process is mainly guided by cognition 
or affect. These insights will help researchers to make conscious decisions about the measurement of risk perception in future research and will inform cancer risk communication practices.

Regarding the first objective, the results supported our two hypotheses concerning the correlations between worry and cognitive and affective likelihood and the twofactor structure of perceived likelihood. Affective likelihood was significantly more strongly correlated with worry in all studies, and the confirmative factor analysis provided support for the two-factor structure of perceived likelihood. These results indicate that it is not preferable to consider rational and intuitive judgements in unison, as has been done in pervious studies (e.g. Champion, 1999; Welch, 2001).

The study further examined associations of cognitive and affective likelihood with four different cancer-related behaviours or intentions. Regression analyses revealed that cancer-related behaviours and intentions were mainly associated with affective likelihood. Affective likelihood was the only perceived likelihood factor related to the intention to quit smoking, current fruit consumption and the intention to quit using sunbeds. For sun protection, significant longitudinal associations were found for both cognitive and affective likelihood. However, affective likelihood was more strongly associated with sunscreen use. These results suggest that affective likelihood may be more relevant to (cancer) related behaviours compared to cognitive likelihood, which replicates and strengthens the results from previous studies (e.g. Janssen et al., 2010; Weinstein et al., 2007), in which affective risk judgements were stronger predictors of health behaviour compared to cognitive probability judgements. Similarly, Denes-Raj and Epstein (1994) showed that feelings are often more compelling compared to the understanding of objective probabilities in the decision-making process. This finding is also in line with the increased notion that there are many situations in which human decisions, judgement and behaviours are not based on rational considerations (Epstein et al., 1992; Slovic \& Peters, 2006; Windschitl \& Wells, 1996). The small correlations often found between perceived likelihood and (cancer related) behaviours (Brewer et al., 2007; Floyd, Pretence-Dunn, \& Rogers, 2000; Harrison, Mullen, \& Green, 1992; McCaul, Reid, Rathge, \& Martinson, 1996; Milne, Sheeran, \& Orbell, 2000) may be related to the fact that most studies to date have used only cognitive operationalisations of perceived likelihood. Similarly, studies investigating the effects of health messages on perceptions of susceptibility, mostly focus on the cognitive component (e.g. Mevissen, Ruiter, Meertens, \& Schaalma, 2010; Vidrine, Simmons, \& Brandom, 2007), thereby precluding the possibility that more affective operationalisations may yield differential results. It is therefore recommended to measure both dimensions of perceived likelihood in future research.

Furthermore, (cancer) risk communication should not only focus on accurate understanding of a certain risk, but should also consider its affective aspects in order to prevent miscommunication. Affective likelihood may benefit from risk communication practices that have a more affective focus using, for example, more affectladen terms (e.g. references to feelings and emotions such as worries about getting cancer) instead of cognition-related terms (e.g. talking about probabilities such as the likelihood of getting cancer). Previous studies showed that persuasive appeals with an affective focus tend to be more successful at changing affective attitudes compared to cognitively oriented messages (e.g. Conner, Rhodes, Morris, McEachan, \& Lawton, 2011; Edwards, 1990; Fabrigar \& Petty, 1999; Mayer \& Tormala, 2010). However, additional research investigating how feelings of 
risk can be influenced is warranted. Furthermore, it would be interesting to investigate under which circumstances affective likelihood is more persuasive. Research investigating possible moderating variables is indispensible to increase our understanding of the effects of affective likelihood on the decision-making process. It could be, for example, that the decision-making process is more influenced by affective likelihood among people that are more affectively oriented and have a higher need for affect (Maio \& Esses, 2001; Mayer \& Tormala, 2010).

Finally, an interesting finding of this study was that the difference in the associations between the outcome measure and cognitive and affective likelihood, respectively, were smaller for the fruit consumption study as compared to the other three studies. This might be due to the fact that fruit consumption does not reduce one specific health threat (e.g. cancer) but has a wide range of health consequences compared to, for example, sun protection. People may therefore have difficulties to express their thoughts and feelings concerning their risk of developing cancer if they do not eat enough fruit. These results also confirm Brewer et al's. (2007) suggestion that risk perceptions are probably more important for behaviours that are intended to reduce a specific health threat and may be less important for behaviours that have a wide range of health consequences, suggesting that the role of perceived likelihood in explaining fruit consumption may be limited.

Some limitations of this study need to be acknowledged. First, three of the four studies had a cross-sectional design so that caution is warranted in the interpretation of the observed associations. Second, moderate-to-highly educated respondents were overrepresented in Study 3 on sun protection and Study 4 on sunbed use, and findings may therefore not be fully generalisable to lower educated people. Finally, cancer-related behavioural intentions were the outcome measures in two studies (i.e. Study 1 on smoking and Study 4 on sunbed use), and although intention is an important precursor of health behaviour (e.g. Ajzen, 1991; Conner \& Norman, 2008), replication of the findings using behavioural outcome measures is recommended.

Despite these limitations, our findings provide support for the validity of the measures used to assess cognitive and affective likelihood and underline the importance of affective likelihood in the decision-making process. The results suggest that affective likelihood might be a better predictor of health behaviour than the commonly used cognitive operationalisation of perceived likelihood and both dimensions of perceived likelihood should therefore be considered in future research and risk communication practices. Future research efforts would benefit from investigating the factors that influence affective probability estimates as these feelings are a powerful correlate of cancer-related behaviours.

\section{Acknowledgements}

This study was financially supported by a grant of the Dutch Cancer Society (KWF Kankerbestrijding).

\section{References}

Ajzen, I. (1991). The theory of planned behavior. Organizational Behavior and Human Decision Processes, 50, 179-211. 
Berndsen, M., \& van der Pligt, J. (2005). Risks of meat: The relative impact of cognitive, affective and moral concerns. Appetite, 44, 195-205.

Borkovec, T.D., Robinson, E., Pruzinsky, T., \& DePree, J.A. (1983). Preliminary exploration of worry: Some characteristics and processes. Behaviour Research and Therapy, 21, 9-16.

Bränström, R., Kristjansson, S., Ullén, H., \& Brandberg, Y. (2002). Stability of questionnaire items measuring behaviours, attitudes and stages of change related to sun exposure. Melanoma Research, 12, 513-519.

Brewer, N., Chapman, G., Gibbons, F., Gerrard, M., McCaul, K., \& Weinstein, N.D. (2007). Meta-analysis of the relationship between risk perception and health behavior: The example of vaccination. Health Psychology, 26, 136-145.

Cameron, L.D. (2008). Illness risk representations and motivations to engage in protective behavior: The case of skin cancer risk. Psychology and Health, 23, 91-112.

Cameron, L.D., \& Reeve, J. (2006). Risk perceptions, worry, and attitudes about genetic testing for breast cancer susceptibility. Psychology and Health, 21, 211-230.

Champion, V.L. (1999). Revised susceptibility, benefits, and barriers scale for mammography screening. Research in Nursing and Health, 22, 341-348.

Cohen, M. (2006). Breast cancer early detection, health beliefs, and cancer worries in randomly selected women with and without a family history of breast cancer. PsychoOncology, 15, 873-883.

Conner, M., \& Norman, P. (2008). Predicting health behaviour. In M. Conner \& P. Norman (Eds.), Predicting health behavior (pp. 1-27). Berkshire: Open University Press.

Conner, M., Rhodes, R.E., Morris, B., McEachan, R., \& Lawton, R. (2011). Changing exercise through targeting affective or cognitive attitudes. Psychology and Health, 2, 133-149.

de Vries, H., Lezwijn, J., Hol, M., \& Honing, C. (2005). Skin cancer prevention: Behaviour and motives of Dutch adolescents. European Journal of Cancer Prevention, 14, 39-50.

de Vries, H., Mudde, A., Leijs, I., Charlton, A., Vartiainen, E., Buijs, G., ..., Kremers, S. (2003). The European smoking prevention framework approach (EFSA): An example of integral prevention. Health Education Research, 18, 611-626.

Denes-Raj, V., \& Epstein, S. (1994). Conflict between intuitive and rational processing: When people behave against their better judgment. Journal of Personality and Social Psychology, 66, 819-829.

Dijkstra, A., De Vries, H., Roijackers, J., \& van Breukelen, G. (1998). Tailoring information to enhance quitting in smokers with low motivation to quit: Three basic efficacy questions. Health Psychology, 17, 513-519.

Dutch Cancer Society (2007). Verstandig zonnen: Minder kans op huidkanker (Wise in the sun: Smaller chance to develop skin cancer) (Brochure). Amsterdam: Dutch Cancer Society.

Edwards, K. (1990). The interplay of affect and cognition in attitude formation and change. Journal of Personality and Social Psychology, 59, 202-216.

Epstein, S., Lipson, A., Holstein, C., \& Huh, E. (1992). Irrational reactions to negative outcomes: Evidence for two conceptual systems. Journal of Personality and Social Psychology, 62, 328-339.

Fabrigar, L.R., \& Petty, R.E. (1999). The role of the affective and cognitive bases of attitudes in susceptibility to affectively and cognitively based persuasion. Personality and Social Psychology Bulletin, 25, 363-381.

Floyd, D.L., Pretence-Dunn, S., \& Rogers, R.W. (2000). A meta-analysis of research on protection motivation theory. Journal of Applied Social Psychology, 30, 407-429.

Hair, J.F., Anderson, R.E., Tatham, R.L., \& Black, W.C. (1998). Multivariate data analysis. Upper Saddle River, NJ: Prentice-Hall.

Harrison, J.A., Mullen, P.D., \& Green, L.W. (1992). A meta-analysis of studies of the health belief model with adults. Health Education Research, 7, 107-116.

Hay, J.L., McCaul, K.D., \& Magnan, R.E. (2006). Does worry about breast cancer predict screening behaviors? A meta-analysis of the prospective evidence. Preventive Medicine, 42, 401-408. 
Hu, L., \& Bentler, P.M. (1999). Cutoff criteria for fit indexes in covariance structure analysis: Conventional criteria versus new alternatives. Structural Equation Modeling: A Multidisciplinary Journal, 6, 1-55.

Janssen, E., van Osch, L., de Vries, H., \& Lechner, L. (2010). Measuring risk perceptions of skin cancer: Reliability and validity of different operationalizations. British Journal of Health Psychology, 16, 92-112.

Janz, N., \& Becker, M.H. (1984). The health belief model: A decade later. Health Education Quarterly, 11, 1-47.

Klein, W., \& Stefanek, M. (2007). Cancer risk elicitation and communication: Lessons from the psychology of risk perception. CA Cancer Journal for Clinicians, 57, 147-167.

Loewenstein, G.F., Weber, E.U., Hsee, C.K., \& Welch, N. (2001). Risk as feelings. Psychological Bulletin, 127, 267-286.

Maio, G.R., \& Esses, V.M. (2001). The need for affect: Individual differences in the motivation to approach or avoid emotions. Journal of Personality, 69, 583-614.

Mayer, N.D., \& Tormala, Z.L. (2010). Think versus feel framing effects in persuasion. Personality and Social Psychology Bulletin, 36, 443-454.

McCaul, K.D., \& Goetz, P. (2008). Worry. Health behavior constructs: Theory measurement, and research. Retrieved from: http://dccps.cancer.gov/brp/constructs/worry/index.html

McCaul, K.D., \& Mullens, A.B. (2003). Affect, thought, and self-protective health behavior: The case of worry and cancer screening. In J. Suls \& K.A. Wallston (Eds.), Social psychological foundations of health and illness (pp. 137-168). New York, NY: Blackwell.

McCaul, K.D., Reid, P.A., Rathge, R.W., \& Martinson, B. (1996). Does concern about breast cancer inhibit or promote breast cancer screening? Basic and Applied Social Psychology, $18,183-194$.

Meng, X.L., Rosenthal, R., \& Rubin, D.B. (1992). Comparing correlated correlation coefficients. Psychological Bulletin, 111, 172-175.

Mevissen, F.E.F., Ruiter, R.A.C., Meertens, R.M., \& Schaalma, H.P. (2010). The effects of scenario-based risk information on perceptions of susceptibility to chlamydia and HIV. Psychology and Health, 25, 1161-1174.

Milne, S., Sheeran, P., \& Orbell, S. (2000). Prediction and intervention in health-related behavior: A meta-analytic review of protection motivation theory. Journal of Applied Social Psychology, 30, 106-143.

Norman, P., Conner, M., \& Bell, R. (1999). The theory of planned behaviour and smoking cessation. Health Psychology, 18, 89-94.

Peters, E., McCaul, K.D., Stefanek, M., \& Nelson, W. (2006). A heuristics approach to understanding cancer risk perception: Contributions from judgment and decision-making research. Annals of Behavioral Medicine, 31, 45-52.

Rogers, R.W. (1975). A protection motivation theory of fear appeals and attitude change. The Journal of Psychology, 91, 93-114.

Schwarzer, R. (1999). Self-regulatory processes in the adoption and maintenance of health behaviors. Journal of Health Psychology, 4, 115-127.

Sharma, S. (1996). Applied multivariate techniques. New York: Wiley \& Sons.

Slovic, P., \& Peters, E. (2006). Risk perception and affect. Current Directions in Psychological Science, 15, 322-325.

Slovic, P., Peters, E., Finucane, M.L., \& MacGregor, D.G. (2005). Affect, risk, and decision making. Health Psychology, 24, S35-S40.

van den Brink, C.L., Ocké, M.C., Houben, A.W., van Nierop, P., \& Droomers, M. (2005). Validering van standaardvraagstelling voeding voor lokale en nationale monitor volksgezondheid (Validation of a community health services food consumption questionnaire in the Netherlands). Bilthoven: Rijksinstituut voor Volksgezondheid en Mileu (RIVM).

Vernon, S.W. (1999). Risk perception and risk communication for cancer screening behaviors: A review. Journal of the National Cancer Institute Monographs, 25, 101-119. 
Vidrine, J.I., Simmons, V.N., \& Brandon, T.H. (2007). Construction of smoking- relevant risk perceptions among college students: The influence of need for cognition and message content. Journal of Applied Social Psychology, 37, 91-114.

Waters, E.A. (2008). Feeling good, feeling bad, and feeling at-risk: A review of incidental affect's influence on likelihood estimates of health hazards and life events. Journal of Risk Research, 11, 569-595.

Weinstein, N.D., Kwitel, A., McCaul, K.D., Magnan, R.E., Gerrard, M., \& Gibbons, F.X. (2007). Risk perceptions: Assessment and relationship to influenza vaccination. Health Psychology, 26, 146-151.

Welch, J.L. (2001). Hemodialysis patient beliefs by stage of fluid adherence. Research in Nursing and Health, 24, 105-112.

Windschitl, P.D. (2003). Measuring and conceptualizing perceptions of vulnerability/likelihood. Paper presented at the Conceptualizing and Measuring Risk Perceptions Workshop, Washington, DC.

Windschitl, P.D., \& Wells, G.L. (1996). Measuring psychological uncertainty: Verbal versus numeric methods. Journal of Experimental Psychology: Applied, 2, 343-364. 